[研究ノート]

\title{
視覚教材「食事バランスマット」を利用した栄養教育の試み
}

\author{
七尾由美子* ·栗津原理恵* ·中村文香* ·市丸雄平** \\ (*金沢学院短期大学，**東京家政大学) \\ (平成25年 5 月 27 日受付，平成25年 8 月 12 日受理)
}

\section{Nutritional education trial for adults using the visual aid "My Placemat for Nutritional Balance"}

\author{
Yumiko Nanao *, Rie Awatsuhara *, Ayaka Nakamura *, Yuhei Ichimaru ** \\ ${ }^{*}$ Kanazawa Gakuin College, 10, Suemachi, Kanazawa-shi, Ishikawa, 920-1392 \\ ** Tokyo Kasei University, 1-18-1, Kaga, Itabashi-ku, Tokyo, 173-8602 \\ *\%920-1392 石川県金沢市末町10 \\ ***173-8602 東京都板橋区加賀1-18-1
}

\begin{abstract}
We tried to make a teaching aid to enable effective use of a Japanese Food Guide Spinning Top. We added milk, dairy products and fruit to an illustration of serving meals of the "one soup with three side dishes" and called the placemat which was printed with the food items which was used a visual aid as "My Placemat for Nutritional Balance".
\end{abstract}

Both BM and BG groups need defining and differentiating. Possibly as 'We intended the use of the placemat for adults and divided volunteers $(n=18)$ into the balance mat $(\mathrm{BM})$ group $(n=9)$. The placemat was also used with a teaching aid of a Japanese Food Guide Spinning Top as the teaching materials for the balance guide (BG) group $(n=9)$ and conducted nutrition education to consider the influence of the different teaching materials'.

As a result of the nutrition study after the education, in the BG group, total amount of food eaten showed a tendency to increase, and consumption of grains and milk increased, but the intake of seafood decreased, and the tendency to consume meat became remarkable. Total amount of food intake decreased in BM group so that the ratio of lean body mass tended to increase. VitaminB $B_{1}$ and iron, that are also less in Japanese meals, decreased due to the reduction of the total intake of meat.

By a question to ask the utility of the questionnaire about the teaching materials, evaluation of the Japanese Food Guide Spinning Top of the BG group was low, but the My Placemat for Nutritional Balance of the BM group was favorably appraised. That is, by use of My Placemat for Nutritional Balance together as a supplementary textbook of the Japanese Food Guide Spinning Top, the possibility of their use as means to improve dietary habits was shown.

\section{1. 緒言}

厚生省・農林水産省・文部省による三省合同の食生活 指針を具体的な行動に結びつけるためのツールとして, 平成17年に食事バランスガイドが策定された。平成 25 年 度より実施される健康日本21（第二次） ${ }^{1)}$ では，基本方
針に生活習慣病の発症予防と重症化予防の徹底を掲げて いる。その中では, 食生活の改善や運動習慣の定着等に よる一次予防に重点を置いた対策を推進するとしている。 その実現のためにも, 食事バランスガイドのさらなる活 用が求められるであろう。しかし, 先行研究では「料理 例がないと迷う」,「自分の食べた料理例が載っていない」 
など，食事バランスガイドの使用感についてわかりにく いとする報告もある ${ }^{2,3)}$ 。そこで，本研究では食事バラ ンスガイドを，より活用しやすくするための補助教材を 作成するにあたり，和食の献立形式の一つである一汁三 菜に着目した。一汁三菜の献立は，米を中心とした主食 に汁物，主菜，副菜，副々菜から構成され，多彩な食材 を盛り达むことができる。この形式は日本人の体質にも 合っており，生活習慣病予防に適した健康食とされ，近 年では海外でも注目されている ${ }^{4-7)}$ 。本研究では，さらに 食事バランスガイドにある料理区分の牛乳・乳製品と果 物を加えて一汁三菜スタイルとし， ランチョンマットと してプリントしたものを視覚教材「食事バランスマット (My Placemat for Nutritional Balance)」と呼称し, 食事 バランスガイドの補助教材として利用することを試みた。

つまり，生活習慣病予防を長期目標とし，食事の自己 管理能力を身につける方法として, 食事バランスマット を使用した教育介入による影響と, 活用への可能性を調 査することを目的とした。

\section{2. 方 法}

\section{(1) 調査期間}

調査は2012年 1 月から 7 月に行った。教育前の身体測 定および栄養調査は，1月21日から31日の間に，教育後 は 7 月21日から31日の間にそれぞれ実施した。集団を対
象とした栄養教育は，2 月 21 日と 22 日に開催し，個人を 対象とした栄養相談は，3 月から 7 月にかけ，1 人に対 しおよそ月に 1 回のペースで実施した。

\section{(2) 対 象 者}

本短期大学の教職員を対象に，2011年12月，学内のイ ンターネット掲示板にて対象者の募集案内を行った。応 募のあった19名に対して研究に関する説明会を開催し,

PowerPoint および書面を用いて趣旨と方法を説明した。 最終的に文書によって研究協力の承諾が得られた者18名 （男性 13 名，女性 5 名; 平均年齢（標準偏差）は 29.2 (5.4）歳）を本研究の対象者とした。

\section{（3）研究の流れ}

研究の流れを図 1 に示した。

1 ) 教育前の調査（2012年 1 月）

2 項に記載の通り, 研究協力が得られた18名に対し, 図 1 に示した教育前の調査を実施した。調査の後, 性別, 年代別に層化し, 無作為割り付けを行った。一方は食事 バランスガイドを主な教材として用いるグループ（以下 BG 群と記す), もう一方は食事バランスガイド+食事 バランスマットを用いるグループ（以下 $\mathrm{BM}$ 群と記す） とした。

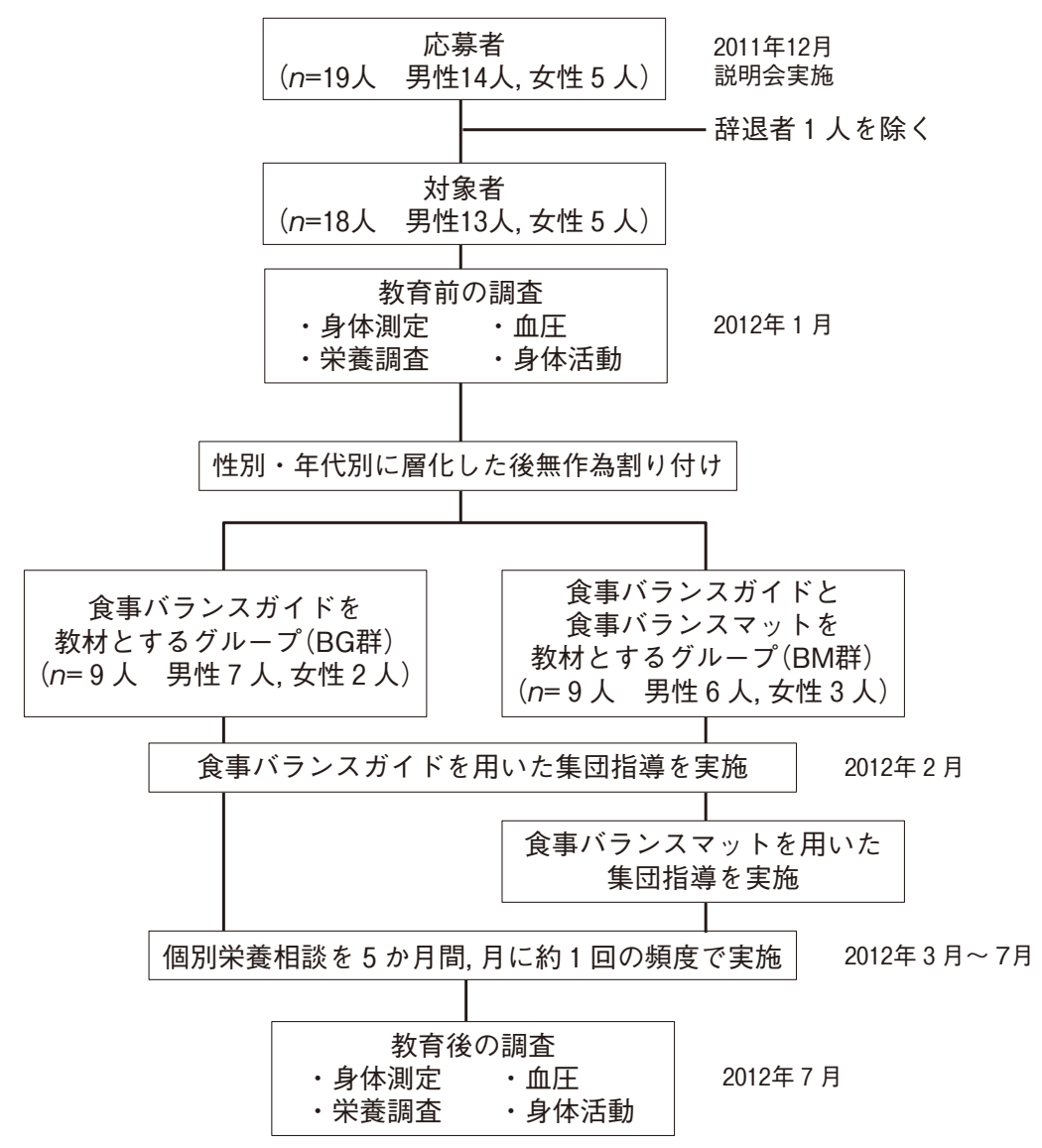

図1 研究の流れ 


\section{2 ）集団教育（2012年 2 月）}

全対象者に対し，食事バランスガイドの使用方法の説 明を加えた集団教育を実施した。次に，BM 群だけを対 象に食事バランスマットを配布し，その使用方法を説明 する集団教育を実施した。

3 ）個別栄養相談（2012年 3 月～ 7 月）

全対象者に対し，1 人あたり月に約 1 回の頻度で個別 栄養相談を実施した。

4 ) 教育後の調查（2012年 7 月）

全対象者に対し，図 1 に示した教育後の調査を実施した。

\section{(4) 調查項目}

\section{1 ) 身体測定}

身体測定は，土曜日の午前中と平日の 17 時以降に行っ た。なお，測定開始前 4 時間は食物掞よび糖質を含む飲 み物をとらないように依頼した。

体組成の評価には，空気置換法によるBODPOD （Ludlum Measurement(陎）を用いた。また，身長計測 とインピーダンス法による体組成測定を InBody J10 （株バイオスペース）で実施した。血圧は，自動血圧計 HBP-9020（オムロン侏）で測定した。BMIは体重 $(\mathrm{kg}) /$ 身長 $(\mathrm{m})^{2}$ の式により算出した。

\section{2 ) 身体活動}

健康づくりのための運動指針2006では，生活習慣病予 防には持久力および筋力が関係するとされ，身体活動の 目安として，歩行中心の活動の場合 1 日あたり拉よそ 8, $000 \sim 10,000$ 歩に相当するとしている ${ }^{8)}$ 。そこで，対 象者の身体活動状沉を把握するため, 加速度計付歩数計 ライフコーダ GS(侏スズケン)を用い, 1 週間の歩数(歩) と活動時間（分）について測定した。ライフコーダ GS をウエスト部，臍と腰を水平に結ぶ線の中点に装着し， 起床時から就寝時まで，入浴時と睡眠時を除く時間帯す べてに装着するように依頼した。

\section{3 ) 栄養調査}

対象者の習慣的な栄養摂取量を把握することを目的に， 食物摂取頻度調査エクセル栄養君 FFQg ver.3. 5 (侏建 帛社）を用いて調查した（以下，FFQg と記載する)。 FFQg は, 29の食品群と10種類の調理法の質問からなり， 調查時点の過去 $1 \sim 2$ 朋の食事状況を思い出し， 1 週 間を単位として摂取量と頻度を問うものである。回答時 間は20分程度で，対象者の習慣的な摂取量を簡便に把握 できる方法であり，その妥当性については高橋ら ${ }^{91} に$ よって報告されている。調査時には記入方法を十分説明 し，栄養士立ち会いのもと回答させた。回収時には記入 もれや記入ミ入を確認し，専用ソフトに入力後，エネル ギーおよび栄養素摂取量と食品群別摂取量を算出した。

\section{4 ) 対象者の生活状況}

対象者 18 名のうち，既婚者で家族と同居は 8 名，残り 10名のうち独身かつ単身生活者は8名であったが，それ ぞれ BM 群， BG 群にほぼ均等に割り当てられた。

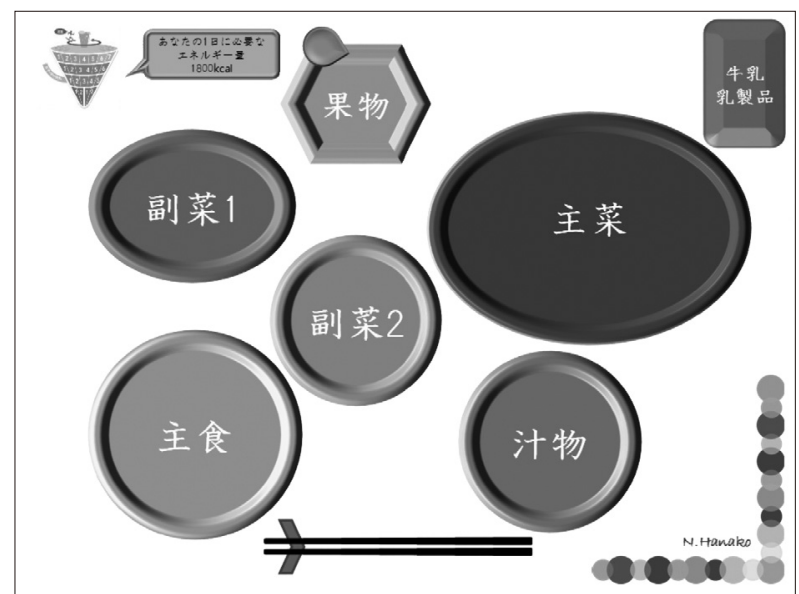

図 2 食事バランスマット

（５）食事バランスマット（My Placemat for Nutritional Balance)

食事バランスマットとは，和食の献立形式の一つであ る一汁三菜に, 食事バランスガイドの料理区分にある果 物と牛乳・乳製品を加え, 料理区分ごとに取り入れるこ とができる食品名を明記した配膳図をイラスト化したラ ンチョンマットである（図 2 )。イラストをA３用紙に カラー印刷し，ラミネート加工を施すことで食卓にラン チョンマットとして敷き，食器をのせて使用できるよう にした。本マットは 1 食分の献立を視覚的に把握できる よう，配膳図とともに，右下には使用者の名前，左上に は食事バランスガイドから求めた使用者の必要エネル ギー量とそれを満たすための料理・食品数を示す SV 数 が示されたコマを記載した。すなわち，対象者の 1 日に 必要な食事量の把握には食事バランスガイドの SV 数を 利用し, 食事バランスマットは，1 食ごとの献立構成, 料理区分別の皿数, 食品の偏りなどを視覚的に把握する ことを目的に利用する補助教材である。

\section{(6) 集団教育}

\section{1 ）全対象者への教育（表 1-1） ステップ 1}

対象者は成人期前半から構成されており，国民健康 · 栄養調査の結果 ${ }^{10)}$ より，この年代は運動習慣者が少ない ことや朝食欠食の者が多いなど，生活習慣病などへの危 機感を感じにくい年代であることが問題点の一つと考え た。生活習慣病予防と健康増進を長期目標とし，テーマ を「バランスのとれた食生活で生活習慣病予防」とした 集団教育を実施した。日本の医療費の現状と問題点を説 明し，自身の健康問題にとどまらず，将来に向けて生活 習慣病の罹患者を少なくすることは，日本の医療保険制 度や介護保険制度にも影響することを認識するよう促し た。

\section{ステップ 2}

生活習慣病予防と健康の維持・増進には, 食生活と適 度な運動が重要ポイントの一つであることを説明した。 
視覚教材「食事バランスマット」を利用した栄養教育の試み

表 1-1 集団教育過程（全対象者）

\begin{tabular}{|c|c|c|c|c|c|c|}
\hline 流れ & 形式 & 時間 & ステップ & 教育内容 & 教育上の留意点 & 教材 · 資料 \\
\hline 導入 & 講義 & 5 分 & & $\begin{array}{l}\text { あいさつ } \\
\text { 本時の目的 }\end{array}$ & $\begin{array}{l}\text { 疾病予防と健康の維持・増進の重要性を理 } \\
\text { 解させる。 } \\
\text { 自身の食生活改善に食事バランスガイドを } \\
\text { 用いるよう動機付けする。 }\end{array}$ & \\
\hline \multirow[t]{3}{*}{ 展開 } & \multirow[t]{3}{*}{ 講義 } & 10分 & ステップ 1 & $\begin{array}{l}\text { 日本の医療費の現状 } \\
\text { と問題点について }\end{array}$ & $\begin{array}{l}\text { 生活習慣病罹患者を少なくすることは, 医 } \\
\text { 療保険制度や介護保険制度にも影響するこ } \\
\text { とを認識させる。 } \\
\text { 成人の生活習慣の特徵と問題点について提 } \\
\text { 起し, 生活習慣病との関連性について認識 } \\
\text { させる。 }\end{array}$ & PowerPoint \\
\hline & & 15分 & ステップ 2 & $\begin{array}{l}\text { 食生活改善と生活習 } \\
\text { 慣病予防, 健康増進 } \\
\text { について }\end{array}$ & $\begin{array}{l}\text { 食事バランスガイドの使用方法を理解させ } \\
\text { る。 } \\
\text { 食生活を改善することで健康の維持, 生活 } \\
\text { 習慣病の予防になることを意識させる。 }\end{array}$ & $\begin{array}{l}\text { PowerPoint } \\
\text { プリント } \\
\quad \text { ·食事バランスガイド } \\
\quad \text { ・料理例の一覽表 }\end{array}$ \\
\hline & & 10分 & ステップ 3 & $\begin{array}{l}\text { 運動習慣と生活習慣 } \\
\text { 病予防, 健康増進に } \\
\text { つてて }\end{array}$ & $\begin{array}{l}\text { 健康づくりのための運動指針2006をもとに, } \\
\text { 運動と生活活動の違い, 運動と健康維持· } \\
\text { 増進の関連性について学ばせる。 }\end{array}$ & PowerPoint \\
\hline まとめ & 講義 & 5 分 & & $\begin{array}{l}\text { 本時のまとめと質疑 } \\
\text { 応答 }\end{array}$ & $\begin{array}{l}\text { 食生活と適度な運動が重要であることを理 } \\
\text { 解させる。 } \\
\text { 生活習慣病予防と健康増進を目指すため, } \\
\text { 食事バランスガイドを使用することを再度 } \\
\text { 強調する。 }\end{array}$ & \\
\hline
\end{tabular}

好ましい食生活を送るための食事について意識してもら うために，食事バランスガイドによって，対象者ごとの 性別，年齢別，身体活動量別に必要とするエネルギー量 の概量と，料理区分別の SV 数を確認させた。食事バラ ンスガイドの主な料理・食品の「つ（SV）」早見表 $\left.{ }^{11}\right)$ (料 理・食品例：68種，お菓子・嗜好飲料 22 種）を利用し, 自身が食べた料理と照らし合わせ，料理区分とSV 数を 確認することによって，1日あたりの望ましい食事量に 調整することが可能であると説明した。

また，単身生活者も多かったため，主食に偏りがちな 食事例を挙げ，手間をかけずに改善できる方法について 説明した。

\section{ステップ 3}

健康づくりのための運動指針2006を紹介し，その中に ある歩数の目標值を例に挙げ，身体活動量を上げること は生活習慣病予防に効果があることを説明した。

2 ) BM 群への教育 (表 1-2)

$\mathrm{BM}$ 群のみを対象に，食事バランスマットの使用方法 についての教育を行った。導入部では，BM 群に配布さ れた食事バランスマットと教育内容について，BG 群の 対象者に口外しないよう注意を促した。

\section{ステップ 1}

一汁三菜は和食の基本的な献立形式の一つであり，主 食, 主菜, 副菜, 副々菜, 汁物から構成され, 食事バラ ンスガイドの牛乳・乳製品と果物を加えることにより， 偏りのない食事が可能になると説明した。

\section{ステップ 2}

食事バランスマットを各自に配布し，料理の配膳方法 を説明し，自身の 1 日に必要なエネルギー量と料理区分 別の SV 数は 1 日 3 食または間食に割り当てるよう教育 した。さらに, 食事バランスマットを食卓で使用し, 献 立構成, 料理区分別の皿数, 食品の偏りなどを確認する よう教育した。

\section{ステップ 3}

「6つの基礎食品」を理解し， 1 群から 6 群の食品を 一汁三菜の各料理に過不足なく取り入れることで，栄養 バランスも良くなると説明した。

\section{（７）個別栄養相談}

\section{1 ）全対象者への教育}

個人を対象に栄養相談を実施した。教育前の調査「(4) 調査項目」 1）～3）功得られた情報を元に，現在の 栄養摂取状況, 身体状況と体重調整の必要性の有無, 減 量を行う場合の運動目標量などを説明した。また, 食事 バランスガイドを用いて, 対象者の各料理区分別の SV 数について再度説明を行い, 栄養調査の結果から算出さ れた SV 数と比較した。

次いで，栄養調査の結果から多くの対象者は脂質エネ ルギー比率が30\%を超えていたため，脂質の摂取量を抑 える方法を説明した。つまり，単に一汁三菜の献立形式 を意識するだけではなく, 脂肪分の少ない食品を選定す ることや，炒め物や揚げ物に偏らず，蒸す，茹でる，電 
表 1-2 集団教育過程（BM 群）

\begin{tabular}{|c|c|c|c|c|c|c|}
\hline 流れ & 形式 & 時間 & ステップ & 教育内容 & 教育上の留意点 & 教材 · 資料 \\
\hline 導入 & 講義 & 3 分 & & $\begin{array}{l}\text { あいさつ } \\
\text { 本時の目的 }\end{array}$ & $\begin{array}{l}\text { 本講義が BM 群にのみ開催されるもので } \\
\text { あることを, 研究の主旨に沿って説明する。 } \\
\mathrm{BG} \text { 群と異なる教材が配布されることを, } \\
\mathrm{BG} \text { 群の対象者には口外しないことを強調 } \\
\text { し, 理解を得る。 }\end{array}$ & \\
\hline \multirow[t]{3}{*}{ 展開 } & \multirow[t]{3}{*}{ 講義 } & 3 分 & ステップ 1 & 一汁三菜について & $\begin{array}{l}\text { 一汁三菜は和食の基本的な献立形式の一つ } \\
\text { であること, また主食, 主菜, 副菜, 副々 } \\
\text { 菜, 汁物で構成されているため, 食材を偏 } \\
\text { りなくとることができることを学ばせる。 }\end{array}$ & \\
\hline & & 10分 & ステップ 2 & $\begin{array}{l}\text { 食事バランスマット } \\
\text { の使用方法について }\end{array}$ & $\begin{array}{l}\text { 食事バランスマットの使用方法について学 } \\
\text { び, 食材の量の把握には食事バランスガイ } \\
\text { ドを参考にすることを説明する。 }\end{array}$ & 食事バランスマット \\
\hline & & 15分 & ステップ 3 & $\begin{array}{l}\text { 食事バランスマット } \\
\text { と6つの基礎食品に } \\
\text { ついて }\end{array}$ & $\begin{array}{l}6 つ の \text { 基礎食品を理解し, 食品を食事バラ } \\
\text { ンスマットの主食・主菜・副菜・副々菜・ } \\
\text { 汁物・乳製品・果物に分別することを学ぶ。 }\end{array}$ & $\begin{array}{l}\text { プリント } \\
\quad \text {. } 6 \text { つの基礎食品と } \\
\quad \text { 配膳図 } \\
\text { プリント内容を拡大した } \\
\text { ポスター }\end{array}$ \\
\hline まとめ & 講義 & 3 分 & & まとめと質疑応答 & $\begin{array}{l}1 \text { 日 } 3 \text { 食, 食事バランスマットを参考にし } \\
\text { て食事内容を考えること, } 6 つ の \text { 基礎食品 } \\
\text { と併せ, 食品を偏りなくとることを再確認 } \\
\text { させる。 }\end{array}$ & \\
\hline
\end{tabular}

子レンジなどの加熱法を活用することで，油脂の摂取量 を抑えることが可能であると教育した。相談時には，詳 細な食生活状況についてインタビューし，栄養士の提案 が実際に活用可能か確認した。また，好ましい食習慣に ついては今後も継続するように伝え，改善点については， 対象者ごとに実施可能な範囲で短期目標を立ててもらい, 次回の個別栄養相談で実行状況を確認した。最後に，対 象者からの食生活に関する質疑応答を行った。

\section{2 ) BM 群への教育}

BM 群には，食事バランスマットを実際に食卓で使用 してもらうよう再度依頼した。その際，(1)汁物について は食塩の過剩摂取につながる可能性があることから, 必 ずしも毎食加える必要はないこと, (2)毎食一汁三菜を揃 えることが難しい場合もあるため，料理区分別に過不足 がある場合は，前後の食事で調整すること，(3)果物や牛 乳・乳製品はデザートや間食に取り入れ，1 日 3 食の中 でライフスタイルに合わせてとること，以上の 3 点を補 足説明した。

\section{（８）食事バランスガイドと食事バランスマットの使用 感アンケート}

熊崎らの調査を参考に ${ }^{12)}$ ，教育後，BG 群はバランス ガイドについて，BM 群は食事バランスガイドと食事バ ランスマット双方の使用感についてのアンケートを行っ た。アンケートの項目は,「自分の食事内容の反省に役 立った」，「食事バランスの大切さが実感できた」，「食事
を考えるうえで参考になった」,「子どもにも使用したい」 「教材の使い方についてどう思うか」，「今後も教材を活 用したいと思うか」の 6 項目を設け，評定尺度法による 5 段階評価とした。評価は，「とても思う（とてもわか りやすい)」5点, 「思う (わかりやすい)」 4 点, 「どち らともいえない」3 点, 「あまり思わない（少しわかり にくい)」2 点, 「全く思わない（わかりにくい）」1点 となるよう配点した。また，「教材の使い方についてど う思うか」と「今後も教材を活用したいと思うか」の項 目では，上記と同様の 5 段階評価とともにその理由を記 入する自由回答欄も設けた。なお，「子どもにも使用し たい」の項目で，現在子どもがいない対象者においては， 将来子どもができた場合を想定して回答するようアン ケート実施時に口頭で説明した。

\section{(9) 解析方法}

集計には Excel 2010（Microsoft (株）を，統計解析に は SPSS Ver.21 for Windows（日本アイ・ビー・エム株） を用いた。定量データは平均值（標準偏差）で示し， 2 群間の比較には Mann-Whitney の $U$ 検定を，各群にお ける教育前後の比較にはWilcoxonの符号付き順位検定 を用いた。さらに，教材の使用感アンケートについては， Mann-Whitneyの $U$ 検定を用いた。なお，対象者が少数 であることから正確確率検定を行い，有意水準は両側検 定で $5 \%$ 未満とした。 


\section{（10）倫理的配慮}

対象者には，2 項に記載した説明会を開催し，参加は 全くの任意であり，いつでも自由にその同意は撤回でき ることを説明した文書および同意書を配布し，同意書へ の署名，押印，提出によって同意を得た。本研究の実施 に際しては，金沢学院大学研究倫理規準に合致している との判断を得て実施された（金学法第117号)。

\section{3. 結果}

\section{（1）身体測定（表 2 )}

身体測定の結果，すべての測定項目において，群間お よび群内で有意な変化は認められなかった。しかし， $\mathrm{BM}$ 群は体脂肪率が1. 8 \% 減少し, 除脂肪体重が $1.1 \mathrm{~kg}$ 増加する傾向が見られた。

\section{（2）身体活動（表 2 ）}

ライフコーダ GS による測定結果から得られたデータ より，下記の項目について述べる。

\section{1 ) 群間比較}

教育前の測定結果より, 歩数 $(p=0.031)$, 活動時間 $(p$ =0.050) ともに, BM 群に比べ BG 群の測定值が有意 に多く，活動的な集団であった。

教育後においても歩数 $(p=0.027)$, 活動時間 $(p=$ 0.046）ともに，BG 群の測定值が有意に多く，両群の 身体活動状況は変わらなかった。

\section{2 ) 群内比較}

BM 群は，教育後の測定において，測定期間中歩行困 難な状況にあり，通常より歩行数が著しく減少した者 1 名を除く 8 名を解析の対象とした。その結果, BM 群, $\mathrm{BG}$ 群ともに，教育前後で歩数と活動時間に関して有意 な変化は認められなかった。なお，2 群ともに教育前よ
りも教育後のほうが歩数と活動時間が減少傾向を示した。

（３）栄養調査 (表 3 )

FFQg の調査結果から得られたデータより，下記の項 目について述べる。

\section{1 ) 群間比較 \\ i ）エネルギーおよび栄養素摂取量}

教育前のエネルギーおよび栄養素摂取量に有意な差は 認められなかった。教育後では, 教育前に比べ 2 群間の 捸取量の差が開く傾向が多くの栄養素等にみられ，ビ夕 ミン $\mathrm{B}_{1}$ 摂取量では, $\mathrm{BG}$ 群に比べ $\mathrm{BM}$ 群が有意に少な かった $(p=0.031)$ 。

\section{ii ）食品群別摂取量}

教育前の食品群別摂取量に有意な差は認められなかっ たが，教育後は肉類の摂取が BM 群で有意に少なかっ た $(p=0.008)$ 。

\section{2 ) 群内比較 \\ i ）エネルギーおよび栄養素摂取量}

BM 群は，教育前に比べ教育後では多くの栄養素等が 減少傾向を示し，特に鉄の摂取量が有意に減少した $(p$ $=0.043)$ が, カルシウム, レチノール当量はやや増加 した。

BG 群は，教育前に比べ教育後では多くの栄養素等が 増加傾向を示した。しかし，ビタミン D の摂取量は教育 後で有意に減少した $(p=0.031)$ 。

\section{ii）食品群別摂取量}

$\mathrm{BM}$ 群は，教育前後の比較では有意な変化は認められ ず，栄養素等と同様に減少傾向を示す食品が多かった。 しかし，緑黄色野菜，その他の野菜，乳類，果実類は増 加傾向を示した。

BG 群は，教育前に比べ教育後では増加傾向を示す食

表 2 教育前後の身体状況および身体活動状況

\begin{tabular}{|c|c|c|c|c|c|c|c|c|c|}
\hline & & \multirow{2}{*}{\multicolumn{2}{|c|}{ 教育前 2 月 }} & \multirow{3}{*}{$\begin{array}{c}\text { 群間差* } \\
\quad p \text { 值 }\end{array}$} & \multirow{2}{*}{\multicolumn{2}{|c|}{ 教育後 7 月 }} & \multirow{3}{*}{$\begin{array}{c}\text { 群間差* } \\
p \text { 值 }\end{array}$} & \multicolumn{2}{|c|}{ 群内差 $(2-7 \text { 月 })^{\dagger}$} \\
\hline & & & & & & & & \multirow{2}{*}{$\begin{array}{c}\text { BM 群 } \\
p \text { 値 }\end{array}$} & \multirow{2}{*}{$\begin{array}{c}\mathrm{BG} \text { 群 } \\
p \text { 值 }\end{array}$} \\
\hline & & $\mathrm{BM}$ 群 $(n=9)$ & $\mathrm{BG}$ 群 $(n=9)$ & & $\mathrm{BM}$ 群 $(n=9)$ & BG 群 $(n=9)$ & & & \\
\hline 身長 & $(\mathrm{cm})$ & $167.7 \quad(7.8)$ & $169.5(5.0)$ & 0.387 & $167.8 \quad(8.0)$ & $169.9 \quad(5.2)$ & 0.387 & 0.660 & 0.129 \\
\hline 体重 & $(\mathrm{kg})$ & $66.7(13.1)$ & $66.2(10.4)$ & 0.730 & $67.0(13.0)$ & $66.3(10.3)$ & 0.796 & 0.359 & 1.000 \\
\hline BMI & $\left(\mathrm{kg} / \mathrm{m}^{2}\right)$ & $23.5 \quad(3.4)$ & $22.9 \quad(3.1)$ & 0.666 & $23.5 \quad(3.1)$ & $22.8 \quad(2.8)$ & 0.546 & 0.496 & 0.641 \\
\hline 体脂肪率 & (\%) & $22.7 \quad(6.5)$ & $20.4 \quad(8.0)$ & 0.190 & $20.9 \quad(7.0)$ & $20.4 \quad(7.3)$ & 0.277 & 0.250 & 1.000 \\
\hline 除脂肪体重 & $(\mathrm{kg})$ & $51.7(11.5)$ & $52.7 \quad(9.4)$ & 0.666 & $52.8(10.2)$ & $52.9(10.0)$ & 1.000 & 0.250 & 0.820 \\
\hline 最高血圧 & $(\mathrm{mmHg})$ & $127 \quad(19)$ & $127 \quad(23)$ & 1.000 & $122 \quad(15)$ & $129 \quad(21)$ & 0.489 & 0.516 & 0.891 \\
\hline 最低血圧 & $(\mathrm{mmHg})$ & (6) & $75 \quad(14)$ & 0.222 & (9) & $70 \quad(12)$ & 0.546 & 0.875 & 0.098 \\
\hline 歩数 & (歩) & 7465 (2159) & $9719(2152)$ & 0.031 & $7061^{\ddagger}(2420)$ & 9651 (1112) & 0.027 & 0.461 & 0.910 \\
\hline 活動時間 & (分) & $313 \quad(189)$ & $451 \quad(169)$ & 0.050 & $262^{\ddagger} \quad(196)$ & 380 & 0.046 & 0.383 & 0.129 \\
\hline
\end{tabular}

数值は平均 (標準偏差)

2 群間の比較には Mann-Whitney の $U$ 検定（正確確率検定）を用いた。 各群の教育前後の比較には Wilcoxonの符号付き順位検定（正確確率検定）を用いた。

測定期間中に歩行困難な状況にあった者 1 名を除く 8 名を解析対象とした。 
表 3 教育前後の食物摂取頻度調査結果

\begin{tabular}{|c|c|c|c|c|c|c|c|c|c|c|c|c|c|c|}
\hline & & & & & j 2 月 & & & & & & & & & \\
\hline & & & & 群 & & 群 & & & 1 群 & $\mathrm{BG}$ & & & BM 群 & BG 群 \\
\hline & & & & $=9)$ & & $=9)$ & $p$ 值 & & $=9)$ & & 9) & $p$ 值 & $p$ 值 & $p$ 值 \\
\hline & エネルギー & (kca & 1946 & (640) & 2035 & 699) & 0.796 & 1710 & (377) & 2085 & (584) & 0.190 & 0.164 & 0.910 \\
\hline & たんぱく質 & $(\mathrm{g})$ & 63.0 & $(160)$ & 66.8 & & 000 & 56.8 & & 67.8 & & 0.094 & & 0.754 \\
\hline & 脂質 & $(\mathrm{g})$ & 67.8 & $(23.9)$ & 74.7 & (30. & 605 & 58.4 & (13 & 72.4 & & 0.063 & & 820 \\
\hline & 炭水化物 & $(\mathrm{g})$ & 255.5 & (104.2) & 235.3 & $(45$ & 666 & 229.2 & $(57$ & 251.9 & & 0.436 & & 359 \\
\hline & カル & & 520 & (177) & 467 & (131) & 0.546 & 559 & & 562 & & 0.666 & & 250 \\
\hline & 鉄 & $(\mathrm{mg})$ & 6.9 & $(2$. & 7. 1 & (2. & 0.796 & 5.9 & (1 & 6.9 & & 0.387 & & 816 \\
\hline & レチノール当量 & $(\mu \mathrm{g})$ & 398 & (123) & 446 & (139) & & 415 & & 478 & & 0.297 & & 734 \\
\hline 養 & ビタミン D & $(\mu \mathrm{g})$ & 4. 1 & (2.0) & 6.4 & (3.9) & 0.258 & 4. 1 & (1. & 4.9 & & 0.931 & & 0.031 \\
\hline 素 & ビタミ & $(\mathrm{mg})$ & 0.85 & $(0.21)$ & 0.89 & & 0.863 & 0.76 & $(0.15)$ & 0.94 & & 0.031 & & 496 \\
\hline & ビタミン $\mathrm{B}_{2}$ & $(\mathrm{mg})$ & 1. 02 & $(0.27)$ & 1.08 & $(0.29)$ & 0.796 & 1.02 & $(0.26)$ & 1. 17 & & 0.161 & & 0.477 \\
\hline & ビタミン C & $(\mathrm{mg})$ & 62 & (30) & 59 & (29) & 0.546 & 64 & & 67 & & 0.666 & & 348 \\
\hline & 食物 & $(\mathrm{g})$ & 11.9 & (4.3) & 10.8 & (4.1) & 0.387 & 10.2 & (3. & 10.4 & (2 & 0.863 & & 0.734 \\
\hline & 食塩 & $(\mathrm{g})$ & 9. 1 & $(4.6)$ & 9.2 & $(4.0)$ & 0.605 & 7.9 & (3. & 10.8 & (4. & 0.222 & & 0.488 \\
\hline & & & & $(2.0)$ & & & & & & & & & & \\
\hline & $\mathrm{F}$ 上 & & 6 & (4. & 2.7 & & 6 & 30.9 & & 32.0 & & 0.546 & & 000 \\
\hline & $\mathrm{C}$ 比 & (1) & 55.1 & (6.6) & 54.1 & (3. & 0.730 & 55.7 & $(5.0)$ & 54.7 & (5.2) & 0.489 & & 938 \\
\hline & & $(\mathrm{g})$ & 1 & 07 . & 7. 8 & $\left(\begin{array}{ll}6 & 2\end{array}\right)$ & 0. & 32.8 & $(80$ & 369.3 & 121 & 0. & & 23 \\
\hline & & $(\mathrm{g})$ & 43. 6 & $(66.2)$ & 22.2 & (15 & 0.730 & 35.7 & $(36$ & 22.9 & & 0.605 & & 000 \\
\hline & 緑黄色里 & $(\mathrm{g})$ & 45.3 & $(21.6)$ & 55.7 & (24. & 0.340 & 52.4 & $(20$ & 53.1 & $(30$ & 0.931 & & 38 \\
\hline & その他 & $(\mathrm{g})$ & 20.9 & $(43.5)$ & 109.2 & (2.6) & 0.605 & 98.9 & $(45.5)$ & 108.0 & & 0.546 & & 934 \\
\hline & & $(\mathrm{g})$ & 3. 1 & $(2.1)$ & 2.3 & (2.6) & 0.436 & 2.4 & & 4.0 & & 0.546 & & 0.078 \\
\hline & 豆類 & $(\mathrm{g})$ & 120.9 & $(46.9)$ & 43.3 & (36.3) & 0.387 & 50.0 & $(25.0)$ & 48.3 & $(28$ & 0.666 & & 0.848 \\
\hline & 魚介類 & $(\mathrm{g})$ & 36.1 & $(26.0)$ & 66.0 & $(49.6)$ & & 35.9 & $(22.1)$ & 43.2 & & 0.931 & & 0.016 \\
\hline 群 & 肉類 & $(\mathrm{g})$ & 81.3 & $(45.0)$ & 97.1 & (39. & 0.863 & 65.4 & $(33.6)$ & 109. 2 & & 0.008 & & 0.160 \\
\hline 別 & 卵類 & $(\mathrm{g})$ & 33.4 & $(12.4)$ & 39.8 & $(20.0)$ & 0.666 & 27.9 & (12.8) & 36.3 & & 0.340 & & 813 \\
\hline 取 & 乳類 & $(\mathrm{g})$ & 122.2 & (103.5) & 94.0 & $(53.7)$ & 0.605 & 206.2 & (147.2) & 184.6 & & & & 0.012 \\
\hline 量 & & $(\mathrm{g})$ & & $(37.5)$ & 31.0 & (32.3) & 0.605 & 43.9 & $(37.7)$ & 48.9 & & 0.546 & & 0.281 \\
\hline & & $(\mathrm{g})$ & & (101.1) & 98.0 & $(60.0)$ & & 61.3 & (64.1) & 69.2 & $(37.0)$ & 0.387 & & 0.211 \\
\hline & 嗜好飲料類 & $(\mathrm{g})$ & 218.4 & (176. 8) & 371.1 & (402.3) & 0.340 & 180.9 & (120.9) & 387.0 & $(540.4)$ & 0.436 & & 1.000 \\
\hline & & $(\mathrm{g})$ & 5.6 & $(4.0)$ & 3.4 & (1.7) & 0.297 & 4. 2 & (3.1) & 4.4 & $(2.7)$ & 0.730 & 0.270 & 0.281 \\
\hline & & $(\mathrm{g})$ & 1.4 & (1.8) & 2.8 & (3.7) & 0.730 & 0.8 & (1.4) & 0.8 & & 0.796 & & 0.188 \\
\hline & & $(\mathrm{g})$ & 15.8 & (9. 1) & 16.3 & $(10.7)$ & 0.666 & 12.1 & $(3.0)$ & 16.9 & & 0.077 & 0.477 & 0.945 \\
\hline & 調味料 - 香辛料 & $(\mathrm{g})$ & 28.0 & $(19.9)$ & 31.3 & (19.9) & 0.605 & 30.1 & $(18.5)$ & 44.0 & (27.3) & 0.297 & 0.977 & 0.215 \\
\hline
\end{tabular}

数值は平均 (標準偏差)

* 2 群間の比較には Mann-Whitneyの $U$ 検定（正確確率検定）を用いた。

各群の教育前後の比較にはWilcoxon の符号付き順位検定（正確確率検定）を用いた。

品が多く, 特に, 穀類 $(p=0.023)$ と乳類 $(p=0.012)$ は有意に増加した。一方, 魚介類 $(p=0.016)$ は有意に 減少し，菓子類は減少傾向を示した。

\section{（4）教材に対する使用感アンケート（表 4)}

\section{1 ）食事バランスガイドの評価}

食事バランスガイドに対する 2 群の評価を比較したと ころ，「子どもにも使用したい」の項目で BM 群の評価 が有意に高かった $(p=0.004)$ 。

2 ) 食事バランスガイドと食事バランスマットの評価 BM 群の食事バランスマットに対する評価と, BG 群 の食事バランスガイドに対する評価を比較した。その結 果,「子どもにも使用したい」 $(p=0.011)$ と「教材の使
い方についてどう思うか」（ $p=0.014 ）$ の項目で, 食事 バランスガイドの評価に比べて，食事バランスマットの 評価が有意に高かった。

さらに，食事バランスマットの使い方についての自由 回答では,「何が必要であるか, 一目瞭然でわかりやすい」, 「食器をのせて食べることができるのでわかりやすい」 といった肯定的な回答が得られた。

\section{4. 考察}

本研究は, 成人を対象とし, 食事バランスガイドを教 材とするグループと，一汁三菜の配膳図をプリントした 食事バランスマットを補助教材として利用するグループ への栄養教育を行い, 群間および群内比較を行った。 
表 4 教材に対する使用感アンケート

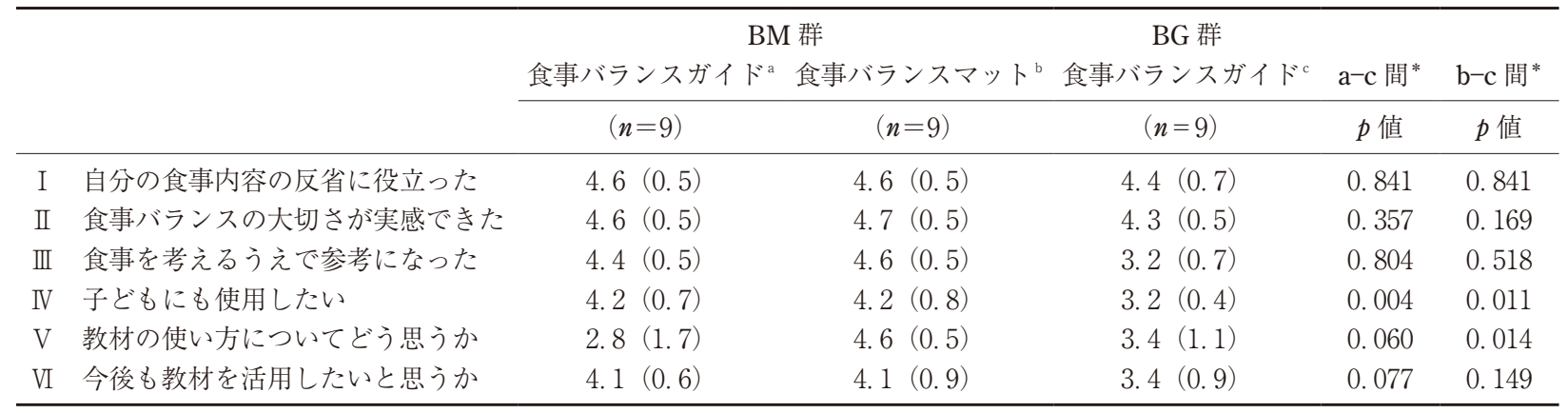

数值は平均点数 (標準偏差)

* 各教材に対する評価の比較には Mann-WhitneyのU検定（正確確率検定）を用いた。

$\mathrm{I} \sim \mathrm{IV}, \mathrm{VI}:\lceil$ とても思う」 5 点, 「思う」4 点,「どちらともいえない」3 点, 「あまり思わない」2 点, 「全く思わない」 1 点

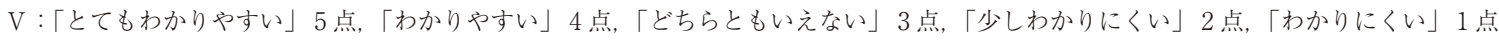

\section{（1）身体測定および身体活動}

身体測定の結果, 群間および群内に有意差は認められ なかったが，BM 群はわずかに体組成に変化がみられた。 これは，教育後の身体活動は 2 群ともに低下傾向にあっ たことから，身体活動以外の要因によるものと推察する。

\section{(2) 栄養調査}

FFQgによる栄養調査の結果, BM 群では多くの食品 摂取量が教育後に減少傾向を示した。このことは食事量 自体が減少したことを示唆するものであり, そのため工 ネルギーおよび栄養素摂取量も減少傾向となり, 特に鉄 は有意に減少する結果となった。

BG 群では教育後に摂取量が増加傾向を示した食品が 多くみられ, 食事量の増加に伴いエネルギーおよび栄養 素摂取量も増加傾向となった。しかし, 魚介類は有意に 減少し, 栄養素ではビタミン D が有意に減少したが, この理由は魚介類の摂取量減少による影響と考えられた。

教育後の群間比較では, BG 群の摂取量が食品群では 肉類, 栄養素等ではビ夕ミン $\mathrm{B}_{1}$ が有意に多かった。ビ 夕ミン $\mathrm{B}_{1}$ は肉類（特に豚肉とその加工品）に多く含ま れることから，ビタミン $\mathrm{B}_{1}$ 摂取量の群間差を生じさせ た原因は，肉類の摂取量増加であると考えられる。

以上のように, 食事量の変化として BM 群では減少 傾向が, BG 群では増加傾向が認められたことについて, それぞれ使用した教材の影響によるものと推察した。つ まり， BM 群では食事バランスマットで食品選択と献立 構成を考えやすくするとともに, 食事バランスガイドで 量の把握を促すねらいで併用させたものの，比較的マッ トのイラストから受ける印象が強く，食事量が抑制され る傾向を生じさせたものと考えられた。一方，BG 群は 食事バランスガイドを利用することにより，これまで摂 取する習慣のなかった食品を摂取しようとすることが食 事量の増加につながったことも予測される。いずれにし ても, 各献立構成と量をともに適正化させるためには, さらなる工夫が必要であると思われた。

\section{（３）食事バランスガイドと食事バランスマットの評価}

BM 群, BG 群，それぞれで使用した教材について， その使用感に関するアンケートを実施した結果, 教材に 対する評価に違いがみられた。

BM 群による食事バランスガイドへの評価では「教材 の使い方についてどう思うか (2.8点)」以外は $4.1 \sim 4.6$ 点の高い評価が得られた。食事バランスマットへの評価 では4. 1〜4.7点と，どの項目も高い評価であった。一方， BG 群の食事バランスガイドに対する評価では,「自分 の食事内容の反省に役立った (4.4点) 」, 「食事バランス の大切さが実感できた (4.3点)」と高い評価であるが, それ以外は3. 2 3. 4点と, 高評は得られなかった。西村 は栄養士養成課程の学生を対象に, 厚生労働省が公表し ている食事バランスガイドによるチェックブックを実際 に活用した後に使用感を調査した。その結果，8割以上 の者が食事改善の必要性を感じる一方,「食事バランス ガイドは参考になったか」の問いに，「どちらともいえ ない」，「参考にならなかった」と回答した者が，「参考 になった」と回答した者を上回ったと報告している ${ }^{13)}$ 。 吉川が行った生活プロデュース学科の学生を対象とした 研究 ${ }^{14)}$ においても, チェックブックを用いた食事診断後 のアンケートでは, 食事バランスガイドの使用感につい て，8割以上の者が「食生活のバランスを考えるときの 目安になると思う」と回答したとある。しかし，「今後 も食事や買い物の参考にしたいか」という問いでは「時々 参考にしたい」という回答が多く，積極的に活用したい という結果には至っていない。本研究の BG 群が高得点 をつけた「自分の食事内容の反省に役立った」,「食事バ ランスの大切さが実感できた」は, 栄養調査の結果示さ れた食事バランスガイドの SV 数によって, 自身の食生 活状況をとらえるきっかけとして有益であり，吉川の研 究結果を支持するものと考える。しかし, 他の質問項目 は食生活を営む上で教材としての実用性を問う内容であ り，それらに対する評価が BG 群で高評を得なかった理 由として, 食事改善の実行手段に食事バランスガイドの 
みを指標にすることは具体性に欠けるためではないかと 推察した。つまり, 食事バランスガイドは食生活改善の 意識の啓発や 1 日あたり食事量の理解には有効であるが, より活用しやすくするためには日々の食生活に導入可能 な食事バランスマットのような補助教材が必要であると 考える。

さらに，食事バランスマットに対する自由回答部分に 抏いても理解しやすいとの肯定的な意見が得られたこと から, 補助教材としての有効性が示唆された。な扮, 結 果には示していないが, 個別栄養相談でも, 本マットは 「使いやすい」というコメントが得られた。初回相談時 には一汁三菜を知らない対象者もいたが，栄養相談を重 ねるに従い配膳図のイメージが定着し, 相談日前夜の食 事内容を聞き取る際には，本マットの配膳図に従い，架 空の皿を目前のテーブルの上に手で並べる様子が観察さ れた。また単身生活者は，扔かずを 3 品揃えることは難 しいが，できるだけマットのイラストの皿が実物の皿で 埋められるように取り組んでいるという対象者もいた。

以上のことから，BM 群， BG 群への体組成や食事内 容について，好ましい影響とともに新たな課題も示され た。これらは，各教材の使用方法について栄養教育内容 の再考, 栄養調査法の検討, 食事バランスマットで食事 量の把握が可能になるよう改良を加えるかなど, 今後の 検討事項である。

教材の使用感に関するアンケートでは，BM 群の食事 バランスガイド，食事バランスマットへの評価は総じて 高く，実用性に関する質問に扔いては BG 群で高評が得 られなかった一方，BM群では高い評価が得られた。

すなわち, 食事バランスガイドの補助教材として食事 バランスマットを併用することは，食生活改善の実行手 段として活用できる可能性が示された。

\section{文献}

1) 厚生労働省：健康日本21 (第二次), 国民の健康の増進の 総合的な推進を図るための基本的な方針, http://www.mhlw. go.jp/bunya/kenkou/kenkounippon21.html

2 ）梅原頼子, 藤原いすず, 川村亜由美：食事バランスガイ ド使用の試み，鈴鹿短期大学紀要，27，125-138（2007）

3 ) 吉川光子：本学学生の食生活意識と「食事バランスガイ ド」の教材としての検討，湘北紀要，30，119-128（2009）

4）大国真彦：子どもの生活習慣病予防に新・一汁三菜のす すめ, 食生活，93，21-26（1999）

5 ）太田百合子：栄養相談に抄ける新・一汁三菜の提案, 食 生活, 93，27-32（1999）

6 ）永山久夫：日本式長寿食の方程式一長寿の秘訣は「一汁 三菜」一, 食の科学, 3，12-18 (2003)

7 ) 永山久夫：世界が注目する江戸時代生まれの「一汁三菜」, 食の科学, 3，12-17 (2004)

8 ）厚生労働省：過去の運動基準・指針, http://www.mhlw. go.jp/seisakunitsuite/bunya/kenkou_iryou/kenkou/undou/ old.html

9）高橋啓子, 吉村幸雄, 開元多恵, 國井大輔, 小松龍史, 山本茂: 栄養素执よび食品群別摂取量推定のための食品群 をべースとした食物摂取頻度調査票の作成揖よび妥当性, 栄養学雑誌, 59 （5）221-232（2001）

10）厚生労働省：平成23年国民健康・栄養調査結果の概要, http://www.mhlw.go.jp/stf/houdou/2r9852000002q1st.html.

11）農林水産省：「食事バランスガイド」活用教材, http:// www.maff.go.jp/j/balance_guide/b_sizai/kaisetusyo.html

12）熊崎稔子, 生田みどり, 伊藤直子, 洼小谷扶美代, 園原 睦子, 中井敦子, 見山新一, 牛田清博：家庭の食事を担っ ている女性の「食事バランスガイド」の認知度と使用感, 愛知新城大谷大学研究紀要, 7, 49-56（2010）

13）西村美津子：栄養士養成課程の学生における献立作成能 力と食事バランスの関連一食事バランスガイドを用いて一, 日本食生活学会誌，21（1）54-59（2010）

14）吉川光子：本学学生の食生活意識と「食事バランスガイ ド」の教材としての検討一認知度, 使用感に関するアンケー 卜調查をもとに一，湘北紀要，30，119-129（2009） 